\title{
Relationship between blood group and gastric carcinoma in Erbil city: A case-control study
}

\section{Abdullah Saeed I brahim ${ }^{1 *}$}

\section{Abstract}

Background and objective: Gastric carcinoma can be caused by the interaction between environmental factors and genetic variations. The relationship between ABO blood groups and carcinogenesis or progression of human tumors has been reported by many investigations. This study aimed to understand the correlation between ABO blood groups and the risk of developing gastric carcinoma.
\end{abstract}

Methods: This case-control study included the ABO blood group and rhesus system of 92 patients diagnosed with gastric carcinoma at Erbil city from 2017 to 2019. Informed consent was obtained from all patients. As a control, the blood group from 260 healthy blood donors was collected from Erbil blood bank.

Results: Of 92 patients, $58.7 \%$ were males, and $41.3 \%$ were females. The mean age was 62 (28 - 97) years. Regarding the type of gastric carcinoma, 58.7\% were intestinal, and $41.3 \%$ were diffuse type. Blood group and rhesus system of patients and control were compared. Blood group $\mathrm{O}$ was $47.8 \%$ in cases versus $40.8 \%$ in control and $42.6 \%$ in all participants, followed by blood group A (31.5\% of gastric carcinoma patients and $26.5 \%$ of control with a total of $27.8 \%$ of all participants). Regarding the Rhesus system, $92.4 \%$ of cases were $\mathrm{Rh}^{+}$, and $7.6 \%$ were $\mathrm{Rh}^{-}$compared with $92.9 \% \mathrm{Rh}^{+}$and $7.1 \% \mathrm{Rh}^{-}$in control. None of them was statistically significant.

Conclusion: There was no statistically significant association between blood groups and gastric carcinoma, although blood group O was more common, followed by $A$.

Keywords: Gastric carcinoma; ABO blood group; Erbil.

\section{Introduction}

Worldwide gastric carcinoma is common in incidence and cancer death. ${ }^{1}$ The first major statistical analysis of cancer incidence and mortality, using data gathered in Verona, Italy, from 1760 to 1839 , showed that gastric carcinoma was the most common and lethal cancer. ${ }^{2}$ It has remained one of the most important malignant diseases with significant geographical, ethnic, and socioeconomic differences in distribution. ${ }^{1,2}$ Worldwide gastric carcinoma is still the fifth most common cancer and the third most common cause of cancer death. ${ }^{2-4}$ About one million patients are newly diagnosed with gastric carcinoma each year, with 700,000 deaths each year. $^{2}$ It is known that gastric carcinoma can be caused by the interaction between environmental factors and genetic variations. ${ }^{3,4}$ As an environmental factor, Helicobacter pylori (H. pylori) infection plays an important role in the development of gastric carcinoma. ${ }^{2,4}$ The first convincing study relating $A B O$ blood group and gastric carcinoma can be traced back to $1953 .{ }^{4,5}$ Blood group $\mathrm{A}$ was found to be associated with gastric carcinoma in the 1950s. This association may be related to the interaction between Lewis blood group antigen and H. pylori. ${ }^{6}$ Since then, the relationship between ABO blood groups and carcinogenesis or progression of human tumors has been reported by many investigations, including increased gastric carcinoma risk in blood

${ }^{1}$ Department of Medicine, college of Medicine, Hawler Medical university, Erbil, I raq.

* Correspondence: abdullah.saeed@hmu.edu.krd 
group $A .^{5-7}$ Studies had been done in different parts of the world. Results were contradicted as most of the studies reported a positive association between gastric carcinoma and blood group $A$ and inverse association for $O$ versus non-O groups. ${ }^{7,8}$ Our region is regarded as a common area for gastric cancer incidence and mortality, with a big burden upon population health. This study aimed to understand the correlation between $A B O$ blood groups and the risk of developing gastric carcinoma. We conducted a case-control study of 92 cases of gastric carcinoma from Erbil and 260 healthy blood donors from Erbil blood bank center.

\section{Methods}

A case-control study was conducted. Demographic data, ABO blood group, and rhesus system of 92 patients diagnosed as gastric carcinoma at Erbil city from 20172019 were included. Informed consent for participation in the study was obtained from all patients. The diagnosis of gastric carcinoma was confirmed histologically; all were adenocarcinoma and classified into two types (diffuse or intestinal). As a control, blood group from 260 healthy blood donors was collected from the Erbil blood bank center for such a purpose. Pearson's Chi-square test was used to compare the distribution of $\mathrm{ABO}$ blood groups between gastric cancer patients and controls. All statistical analyses were performed with the statistical package for the social sciences (version 20.0). Chi square test of association was used to show the association between the blood groups and different factors. A $P$ value of $<0.05$ indicated statistically significant differences.

\section{Results}

Of 92 cases, 54 were males (58.7\%), and 38 were females $(41.3 \%)$. The mean age was 62 years (range 28 - 97 years). Regarding ethnicity, $89.1 \%, 9.8 \%$, and $1.1 \%$ of cases were from Kurdish, Arabic, and Turkman, respectively. Regarding the type of gastric cancer, $58.7 \%$ was from the intestinal type, and the remaining $41.3 \%$ was from the diffuse type, as shown in Table 1.

Table 1 Variables of patients with gastric cancer

\begin{tabular}{lcc}
\hline Variable & No. & (\%) \\
\hline Sex & 54 & $(58.7)$ \\
Male & 38 & $(41.3)$ \\
Female & & \\
Ethnicity & 82 & $(89.1)$ \\
Kurd & 9 & $(9.8)$ \\
Arab & 1 & $(1.1)$ \\
Turkman & & \\
Type of cancer & 54 & $(58.7)$ \\
Intestinal & 38 & $(41.3)$ \\
Diffuse & 92 & $(100)$ \\
Total & & \\
\hline
\end{tabular}


The blood groups and rhesus of patients were as follow: $\mathrm{O}+39$ (42.4\%), $\mathrm{O}-5$ (5.4\%), A+ 27 (29.3\%), A- 2 (2.2\%), B+ 12 $(13.0 \%), B-0(0 \%), A B+7(7.6 \%)$ and AB- 0 (0\%), as shown in Figure 1.

Blood group and rhesus system of patients with gastric cancer and control were compared. Blood group $\mathrm{O}$ was prevalent in $47.8 \%$ of cases versus $40.8 \%$ of control, with $42.6 \%$ of all participants, followed by blood group A (31.5\% of cases and $26.5 \%$ of control, with a total of $27.8 \%$ of all participants). None of them was statistically significant. As far as the rhesus system is concerned, $92.4 \%$ of the cases were Rh (positive), and 7.6 were Rh (negative) compared with 92.9\% Rh (positive) and $7.1 \% \mathrm{Rh}$ (negative) in control. Also, they were not statistically significant, as shown in Table 2.

Table $2 \mathrm{ABO}$ and rhesus system of cases and control

\begin{tabular}{llcccc}
\hline Variable & & $\begin{array}{c}\text { Case } \\
\text { No. (\%) }\end{array}$ & $\begin{array}{c}\text { Control } \\
\text { No. (\%) }\end{array}$ & $\begin{array}{c}\text { Total } \\
\text { No. (\%) }\end{array}$ & P value \\
\hline ABO system & O & $44(47.8)$ & $106(40.8)$ & $150(42.6)$ & 0.142 \\
& A & $29(31.5)$ & $69(26.5)$ & $98(27.8)$ & \\
& B & $12(13)$ & $63(24.2)$ & $75(21.3)$ & \\
Rhesus system & RB & $7(7.6)$ & $22(8.5)$ & $29(8.2)$ & \\
& Rh & $85(92.4)$ & $242(93.1)$ & $327(92.9)$ & 0.826 \\
& & $7(7.6)$ & $18(6.9)$ & $25(7.1)$ & \\
Total & $92(100)$ & $260(100)$ & $352(100)$ & \\
\hline
\end{tabular}

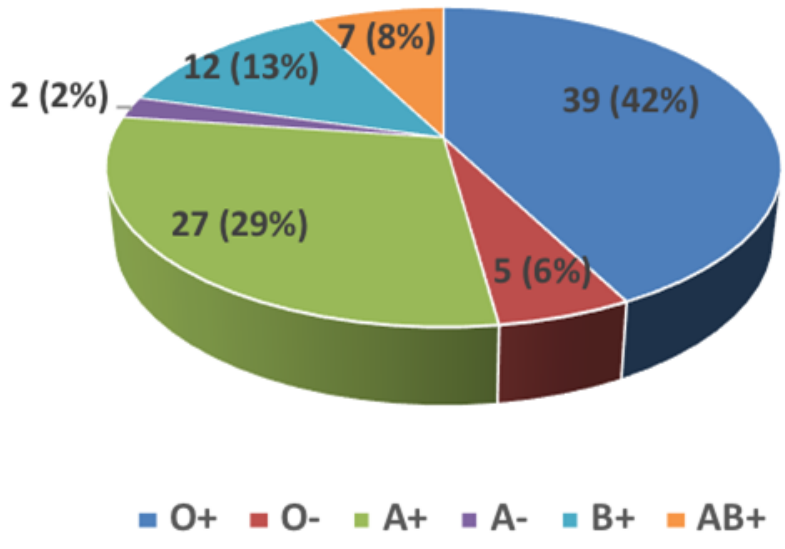

Figure 1 Blood group and rhesus of patients with gastric cancer 
To show the charismatics of patients with gastric carcinoma and their relation with blood group and correlation with Rh system of the patients, the study revealed that up to $50 \%$ of patients with blood group $\mathrm{O}$ were males and $33.3 \%$ were from blood group A. The difference was not significant statistically, as shown in Table 3.

\section{Discussion}

The present study shows that males are predominant in gastric cancer, which is comparable with other studies showing that gastric cancer is more common in males. $^{3,5,10,11}$

Up to $47.8 \%$ of the cases of gastric cancer were from blood group $\mathrm{O}$, and $31.5 \%$ were from blood group $A$; this is contrary to other studies in which more association with blood group $\mathrm{A}$ is reported. ${ }^{3,8,11,12} \mathrm{~A}$ total of 36 studies, including 31783 cancer cases, investigated the association between gastric cancer and ABO blood groups, including 35 case-control studies and one cohort study. Seven studies were performed in Asia, and 29 were performed in Europe. Most of the studies reported a positive association between gastric cancer and blood group $A$ and an inverse association for $O$ vs. non-O groups. Five studies reported a contrary result which was not statistically significant. This difference could be explained by that blood group $\mathrm{O}$ is more common in our country as $40.8 \%$ of the control group were from blood group O while $26.5 \%$ were from blood group $A$. Blood group $O$ is more prone to $H$. pylori infection most probably due to the higher frequency of secretor status in the individuals of blood group $\mathrm{O}$ that $\mathrm{H}$ antigen represents an important receptor expressed in the gastroduodenal mucosal cells to which $H$. pylori adheres, which also enhances colonization of $H$. pylori bacteria which has an association with $H$. pylori infection and chronic gastritis, then intestinal metaplasia, then gastric cancer development. ${ }^{12,13}$

Table 3 Characteristics of patients with gastric carcinoma and their relation to blood groups and Rh

\begin{tabular}{|c|c|c|c|c|c|c|c|c|c|}
\hline Variable & & $\begin{array}{c}0 \\
N=44 \\
(\%)\end{array}$ & $\begin{array}{c}A \\
N=29 \\
(\%)\end{array}$ & $\begin{array}{c}B \\
N=12 \\
(\%)\end{array}$ & $\begin{array}{l}A B \\
N=7 \\
(\%)\end{array}$ & $P$ value & $\begin{array}{c}\text { Rh+ } \\
\mathrm{N}=85 \\
(\%)\end{array}$ & $\begin{array}{l}\text { Rh- } \\
\mathrm{N}=7 \\
(\%)\end{array}$ & $P$ value \\
\hline \multirow[t]{2}{*}{ Sex } & Male & $\begin{array}{c}27 \\
(50)\end{array}$ & $\begin{array}{c}18 \\
(33.3)\end{array}$ & $\begin{array}{c}7 \\
(13)\end{array}$ & $\begin{array}{c}2 \\
(3.7)\end{array}$ & 0.440 & $\begin{array}{c}49 \\
(90.7)\end{array}$ & $\begin{array}{c}5 \\
(9.3)\end{array}$ & 0.695 \\
\hline & Female & $\begin{array}{c}17 \\
(44.7)\end{array}$ & $\begin{array}{c}11 \\
(28.9)\end{array}$ & $\begin{array}{c}5 \\
(13.2)\end{array}$ & $\begin{array}{c}5 \\
(13.2)\end{array}$ & & $\begin{array}{c}36 \\
(94.7)\end{array}$ & $\begin{array}{c}2 \\
(5.3)\end{array}$ & \\
\hline \multirow[t]{3}{*}{ Ethnicity } & Kurd & $\begin{array}{c}37 \\
(45.1)\end{array}$ & $\begin{array}{c}26 \\
(31.7)\end{array}$ & $\begin{array}{c}12 \\
(14.6)\end{array}$ & $\begin{array}{c}7 \\
(8.5)\end{array}$ & 0.753 & $\begin{array}{c}76 \\
(92.7)\end{array}$ & $\begin{array}{c}6 \\
(7.3)\end{array}$ & 0.566 \\
\hline & Arab & $\begin{array}{c}6 \\
(66.7)\end{array}$ & $\begin{array}{c}3 \\
(33.3)\end{array}$ & $\begin{array}{c}0 \\
(0)\end{array}$ & $\begin{array}{c}0 \\
(0)\end{array}$ & & $\begin{array}{c}8 \\
(88.9)\end{array}$ & $\begin{array}{c}1 \\
(11.1)\end{array}$ & \\
\hline & Turkman & $\begin{array}{c}1 \\
(100)\end{array}$ & $\begin{array}{c}0 \\
(0)\end{array}$ & $\begin{array}{c}0 \\
(0)\end{array}$ & $\begin{array}{c}0 \\
(0)\end{array}$ & & $\begin{array}{c}1 \\
(100)\end{array}$ & $0(0)$ & \\
\hline \multirow[t]{2}{*}{$\begin{array}{l}\text { Types of } \\
\text { Cancer }\end{array}$} & Intestinal & $\begin{array}{c}24 \\
(44.4)\end{array}$ & $\begin{array}{c}20 \\
(37)\end{array}$ & $\begin{array}{c}7 \\
(13)\end{array}$ & $\begin{array}{c}3 \\
(5.6)\end{array}$ & 0.505 & $\begin{array}{c}50 \\
(92.6)\end{array}$ & $\begin{array}{c}4 \\
(7.4)\end{array}$ & 1 \\
\hline & Diffuse & $\begin{array}{c}20 \\
(52.6)\end{array}$ & $\begin{array}{c}9 \\
(23.7)\end{array}$ & $\begin{array}{c}5 \\
(13.2)\end{array}$ & $\begin{array}{c}4 \\
(10.5)\end{array}$ & & $\begin{array}{c}35 \\
(92.1)\end{array}$ & $\begin{array}{c}3 \\
(7.9)\end{array}$ & \\
\hline
\end{tabular}


Regarding Rh system, most cases of gastric carcinoma were from $\mathrm{Rh}+(92.4 \%)$ versus $\mathrm{Rh}-(7.6 \%)$. This is similar to other studies. ${ }^{13,14}$ Regarding $\mathrm{Rh}$ of the control group, it was nearly the same, just like the ones of affected persons.

As far as ethnicity is concerned, most of the cases were Kurdish (89.1\%), followed by Arabic (9.8\%), and $1.1 \%$ were from Turkman ethnic group. This could be explained by the area where most of the inhabitants are Kurds. As far as the types of gastric cancer are concerned, $58.7 \%$ were of intestinal type whereas the remaining was from diffuse type. This could be explained by that intestinal type is mostly associated with the background of $H$. pylori associated gastropathy, and our country is unfortunately of a high prevalence of $H$. pylori. ${ }^{12}$

\section{Conclusion}

There was no statistically significant association between blood groups and gastric carcinoma, although blood group $\mathrm{O}$ was more common, followed by $A$.

\section{Funding}

None.

\section{Competing interests}

None declared.

\section{References}

1. Siegel R, Naishadham D, Jemal A. Cancer statistics. CA Cancer J Clin. 2013; 63(1):11-30. https://doi.org/10.3322/caac.21166.

2. Nakao M, Matsuo K, Ito H, Shitara K, Hosono S, Watanabe $M$, et al. $A B O$ genotype and the risk of gastric cancer, atrophic gastritis, and Helicobacter pylori infection. Cancer Epidemiol Biomarkers Prev. 2011; 20(8):1665-72. https://doi.org/10.1158/1055-9965.EPI-11-0213.

3. Wang Z, Liu L, Ji J, Zhang J, Yan M, Zhang J, et al. ABO blood group system and gastric cancer: a case-control study and meta-analysis. Int J Mol Sci. 2012; 13(10):13308-21. https://doi.org/10.3390/iims131013308.

4. Liumbruno GM, Franchini $M$. Beyond immunohaematology: The role of the $A B O$ blood group in human diseases. Blood Transfus. 2013; 11(4):491-9. https://doi.org/10.2450/2013.0152$\underline{13}$.
5. Edgren G, Hjalgrim $H$, Rostgaard $K$, Norda R, Wikman A, Melbye M, et al. Risk of gastric cancer and peptic ulcers in relation to $A B O$ blood type: a cohort study. Am J Epidemiol. 2010; 172(11): 1280-5. https://doi.org/10.1093/aje/kwq299.

6. Heike I, Grabscha B, Patrick T. Gastric Cancer Pathology and Underlying Molecular Mechanisms. Dig Surg. 2013; 30:150-8. https://doi.org/10.1159/000350876.

7. Rawla P, Barsouk A. Epidemiology of gastric cancer: global trends, risk factors and prevention. Prz Gastroenterol. 2019; 14(1):26-38. https://doi.org/10.5114/pg.2018.80001.

8. Zhang $\mathrm{BL}, \mathrm{He} \mathrm{N}$, Huang $\mathrm{YB}$, Song $\mathrm{FJ}$, Chen KX. ABO blood groups and risk of cancer: a systematic review and meta-analysis. Asian Pac J Cancer Prev. 2014; 15(11):4643-50. https://doi.org/10.7314/apjcp.2014.15.11.4643.

9. Ali Z, Bhaskar SB. Basic statistical tools in research and data analysis. Indian J Anaesth. 2016; 60(9):662-9. https://doi.org/10.4103/00195049.190623.

10. Karimi $\mathrm{P}$, Islami $\mathrm{F}$, Anandasabapathy $\mathrm{S}$, Freedman ND, Kamangar F. Gastric cancer: descriptive epidemiology, risk factors, screening, and prevention. Cancer Epidemiol Biomarkers Prev. 2014; 23(5):700-13. https://doi.org/10.1158/1055-9965.EPI-13-1057.

11. Chakrani Z, Robinson K, Taye B. Association between $\mathrm{ABO}$ blood groups and Helicobacter pylori infection: A Meta-Analysis. Sci Rep. 2018; 8:17604. https://doi.org/10.1038/s41598-01836006-X.

12. Jaff MS. Relation between $A B O$ blood groups and Helicobacter pylori infection in symptomatic patients. Clin Exp Gastroenterol. 2011; 4:221-6. https://doi.org/10.2147/CEG.S23019.

13. Lahmidani N, El Yousf M, Aqodad N, Benajah D, El Abkari M, Ibrahimi A, et al. Update on gastric cancer epidemiology and risk factors. Journal of Cancer Therapy. 2018; 9(3):242-54. https://doi.org/10.4236/ict.2018.93021.

14. Cotoi BV, Georgescu I. An epidemiological assessment of gastric cancer. CHSJ. 2010; 36(2): 74-7. https://doi.org/10.12865/CHSJ.36.02.05. 